\title{
The pygmy field mouse - what does influence food quality?
}

\author{
E. Janova ${ }^{1,2}$ and M. Heroldova ${ }^{3}$
}

\begin{abstract}
${ }^{1}$ Department of Animal Genetics, Faculty of Veterinary Medicine, University of Veterinary and Pharmaceutical Sciences, Palackeho 1, 61242 Brno, Czech Republic. Corresponding author.Email: janova.eva@seznam.cz ${ }^{2}$ Ceitec VFU, University of Veterinary and Pharmaceutical Sciences, Palackeho 1, 61242 Brno, Czech Republic 3 Institute of Forest Ecology, Mendel University in Brno, Faculty of Forestry and Wood Technology, Zemedelska 3, 61300 Brno, Czech Republic
\end{abstract}

Keywords: Apodemus uralensis, Dietary quality, Microtus arvalis, Nitrogen content.

\begin{abstract}
The dominant rodent species in Central European agricultural landscapes are granivorous mouse species and herbivorous common voles. Although our knowledge of European wood mice is relatively good, there is a distinct lack of information on pygmy field mice inhabiting Central and Eastern Europe and Central Asia. In this study, we examine the food quality of pygmy field mice in relation to environmental and population factors, and compare the food quality of related mouse species and common voles living in the same study plots. The dietary quality of the pygmy field mouse is similar to that of other mouse species; however, the food quality of pygmy field mice and common voles differed substantially, with mice having lower and more variable nitrogen content. For both rodent species, factors such as body size, age and sex had no influence on diet quality. Pygmy field mouse diet was mainly dependent on season, while total abundance had greatest influence on common vole diet.
\end{abstract}

Abbreviations: AS-wood mouse; AU-pygmy-field mouse; GLM-generalized linear models; MA-common vole; NC-Nitrogen Content; NIRS-infrared reflectance spectroscopy.

\section{Introduction}

The most common rodents in Central European arable landscapes are the herbivorous common vole (Microtus arvalis, Pallas 1778) and granivorous mouse species. Although our knowledge of the most common mice species in agricultural landscape, the wood mouse (Apodemus sylvaticus, Linnaeus 1758), is extensive, there is far less information available on the pygmy field mouse (Apodemus uralensis, Pallas 1811), which, under some conditions, can be more abundant than the wood mouse. This is due, in part, to the species' absence in Fennoscandia and the British Isles (Panteleyev 1998), where rodent communities with dominant wood mouse, have been widely studied (e.g., Loman 1991, Tattersall et al. 1999, Todd et al. 2000, MacDonald et al. 2007, Broughton et al. 2014).

The Czech Republic represents the western-most border of pygmy field mouse distribution (Storch 1999, Cichocki et al. 2011). According to Hoofer et al. (2007) and Cichocki et al. (2011), the pygmy field mouse does not form dense populations; our own observations, however, show that changes in population size can be rapid, in both time and space. In fact, populations can achieve high densities and the species may become the dominant rodent species for a time, though it may then be absent from the same region for some time (Heroldova et al. 2004, Janova et al. 2016). Set-aside plots are the preferred habitat of the pygmy field mouse (Zejda and Nesvadbova 1996, Heroldova et al. 2005) and the species is generally granivorous (Holisova et al. 1962, Heroldova 1994), as reflected in the length of its gastrointestinal tract, which is generally shorter than that of herbivorous voles (Heroldova and Janova 2018). Though it is generally known that food quality plays a key role in population specific traits such as body size, reproduction rate, population dynamics and life history (e.g., Hansson 1979, White 1993, Sibly and Hone 2002, Wereszynska et al. 2007, Forbes et al. 2014), we know practically nothing about food quality parameters of pygmy field mouse populations.

In this study, we undertook a wide-ranging study on the effects of food quality on the pygmy field mouse. In doing so, we compare the dietary quality of pygmy field mice with other sympatric mouse species- wood mouse and yellow-necked mouse (Apodemus flavicolis, Melchior, 1834) and the common vole. Secondly, we assess which external and internal factors influence the quality of the food consumed by these rodents. For this, infrared reflectance spectroscopy (NIRS) was used. This method was originally developed and validated for the estimation of nitrogen content (NC) in rodent stomachs (Cepelka et al. 2014, Janova et al. 2015).

\section{Material and methods}

\section{Population sampling}

In the set-aside plots, sampling was undertaken in January 2001 and then monthly between May 2001 and September 2003 within the agricultural landscape surrounding the village of Drnholec ( $\left.48^{\circ} 53^{\prime} 30^{\prime \prime} \mathrm{N}, 16^{\circ} 27^{\prime} 30^{\prime \prime} \mathrm{E}\right)$ in the South Moravian Pannonian lowland of the Czech Republic. In addition, rodents sampled irregularly from winter wheat and winter rape fields adjacent to the set-aside plots between March and September were used (for more details about trapping ef- 
Table 1. The number of individuals, trapping sessions (No. of trapping sessions) and traps per session (No. of traps/session) analysed from set-aside (Drnholec), wheat and rape fields (Drnholec + Nosislav). Values for nitrogen content (NC) are in $\mathrm{g} / \mathrm{kg}$ of dry biomass.

\begin{tabular}{|c|c|c|c|c|c|c|c|}
\hline Habitat & Locality & $\begin{array}{l}\text { No. of } \\
\text { trapping } \\
\text { sessions }\end{array}$ & $\begin{array}{c}\text { No. of traps/ } \\
\text { session }\end{array}$ & Species & No. total & $\mathrm{NC} \pm 95 \%$ range & $\mathrm{NC}$ median \\
\hline \multirow[t]{4}{*}{ Set-aside } & Drnholec & 30 & 300 & Pygmy field mouse & 205 & $104-466$ & 247 \\
\hline & & & & Common vole & 383 & $199-433$ & 309 \\
\hline & & & & Wood mouse & 35 & $100-448$ & 249 \\
\hline & & & & Yellow necked mouse & 8 & $182-397$ & 299 \\
\hline \multirow[t]{3}{*}{ Wheat } & Drnholec + Nosislav & $6+9$ & $150+100$ & Pygmy field mouse & 17 & $82-409$ & 216 \\
\hline & & & & Common vole & 46 & $152-366$ & 245 \\
\hline & & & & Wood mouse & 37 & $18-476$ & 243 \\
\hline \multirow[t]{3}{*}{ Rape } & Drnholec + Nosislav & $3+11$ & $100+100$ & Pygmy field mouse & 15 & $142-554$ & 206 \\
\hline & & & & Common vole & 19 & $195-515$ & 287 \\
\hline & & & & Wood mouse & 65 & $100-596$ & 311 \\
\hline
\end{tabular}

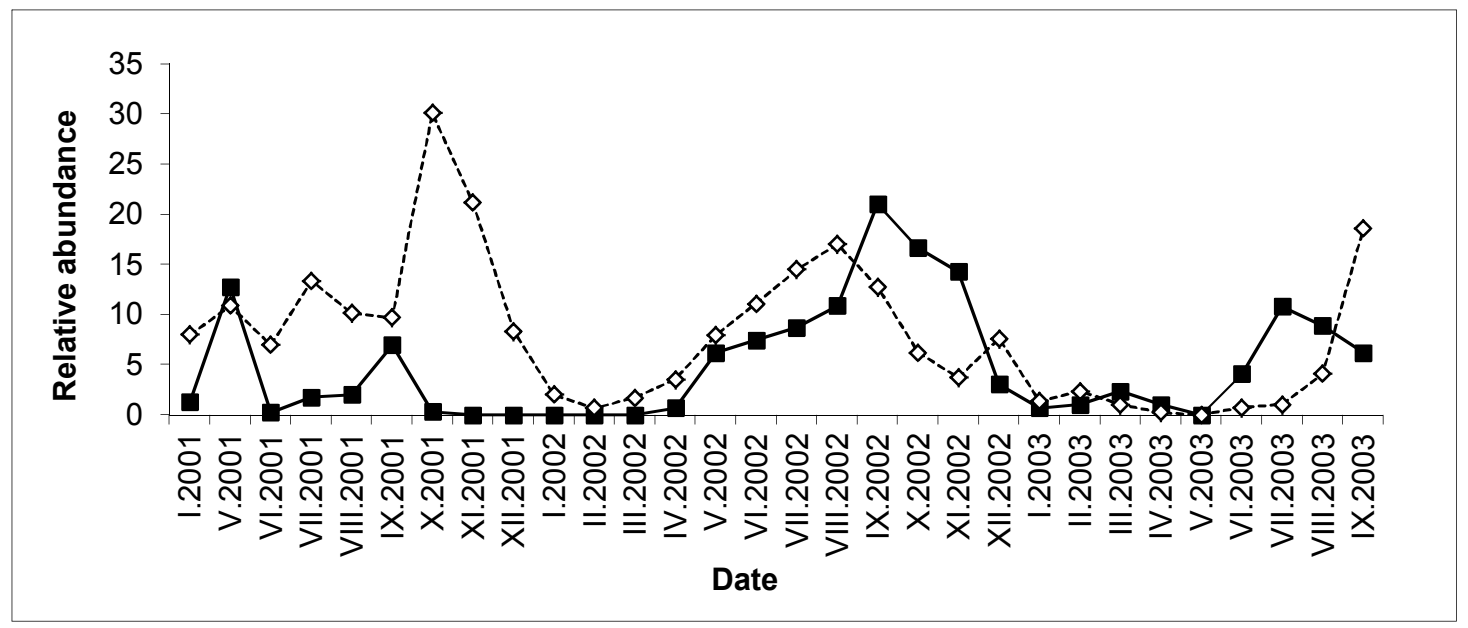

Figure 1. The relative abundances (number of individuals per 100 traps) of pygmy field mouse (solid line) and common vole (dashed line) in the set-aside plots.

fort see Table 1). As wheat and rape fields are non-typical habitats for pygmy field mice, the number of individuals captured was relatively low. Hence, as a second step, we also included individuals caught in wheat and rape fields surrounding the village Nosislav (4900'77" N, $16^{\circ} 65^{\prime} 72^{\prime \prime}$ E), approximately 20 $\mathrm{km}$ from Drnholec, between 2008 and 2009 (Table 1). All sampling was performed using snap traps baited with fried wicks and exposed for one night in lines of 100 traps $3 \mathrm{~m}$ apart.

We defined the population size during each trapping session as relative abundance, i.e. the number of individuals caught per 100 trap-nights. Numbers were recorded as total abundance (i.e., total number of individuals of all species), which reflects the total impact of rodents on local food and environmental resources, and species-specific abundance (i.e. the relative abundance of pygmy field mice and common voles separately). The species relative abundances of pygmy field mouse and common vole ranged from 0 to 44 (for detailed information about relative abundance in set-aside plots, see Fig. 1).

All individuals captured were sexed, measured and dissected. The age of each individual was assessed as adult or sub-adult, based on signs of breeding activity (adult females have embryos or placental scars, males have testes larger than $7 \mathrm{~mm}$ and enlarged epididymis).

\section{Food analysis}

The successional set-aside plots where sampling took place were all previously alfalfa fields, sampling taking place three years after the last crop. Vegetation consisted of weed species with some self-seeded alfalfa, which gradually decreased in biomass over time. The dominant weed species were chickweed (Stellaria media) and shepherd's purse (Capsella bursa pastoris), followed by tumbleweed (Amaranthus retroflexus), lambs quarters (Chenopodium album), false mayweed (Matricaria maritima), dandelion (Taraxacum officinale), horseweed (Erigeron canadensis) and brome grasses (Bromus sp.). Around 48 weed species in all were recorded in a similar later succession plot (Heroldova et al. 2005). 
Primary dietary analysis for the pygmy field mouse and common vole, undertaken according to Holisova and Obrtel (1984), is presented in a separate study (Heroldova and Janova 2018). Overall, seeds (especially lambs quarters and tumbleweed) dominated pygmy field mouse diet throughout the year, with chickweed preferred in spring. In addition, the mouse also took crop seeds from neighbourhood fields just after sowing and harvesting. For voles, the green parts of plants dominated throughout the year, with alfalfa being replaced by the green parts of weed species as succession progressed. In winter, the diet shifted to grasses and roots.

\section{Estimation of food quality}

Following dissection, each stomach was removed and dried. NIRS analysis was then used to estimate NC on the larger samples, i.e. larger than the NIRS detection window and thick enough that a light beam would not penetrate. The samples were then repeatedly scanned (each $50 \times$ ) with a Nicolet Antaris II FT-NIR near infrared spectrometer (Thermo Scientific, USA) over a 1100-2500 nm wavelength range, thus covering the complete physical and chemical composition of the samples. These samples were calibrated based on 34 stomachs simultaneously analysed by the classic Kjeldahl method, the calibration model being based on a least square regression of both chemometric and NIRS samples. Twenty independent stomach samples were used for calibration validation and verification. For further details on calibration and verification, see Janova et al. (2015) and Cepelka et al. (2017). Food quality was expressed as the percentage of total $\mathrm{NC}\left(\mathrm{NC}=\mathrm{N}^{*} 6.25\right)$ in total stomach content dry matter (according to AOAC, 1990).

\section{Statistical analysis}

We examined pygmy field mouse diet quality by three viewpoints. First, we analysed diet quality in relation to individual and environmental parameters in the mouse population from set-aside plots, where the sample size was large enough. This was done also for the numerous sympatric common vole population. Secondly, we compared pygmy field mouse NC with that of other mice species in the same habitat. Third, we compared the differences in NC of pygmy field mouse and other more abundant rodent species between habitats.

The analysis of influence of individuals and environmental parameters on NC values of pygmy field mouse and common vole population takes place in two steps. During the first step, the effect of all consequent variables on $\mathrm{NC}$ was analysed in one model using a multivariate generalised linear modelling (GLM): "species" (pygmy field mouse and common vole), body length, sex, age, date, year, total abundance and species abundance. From this analysis, the effect of the species was figured out. During the second step, we computed the same GLM analysis but for each species separately using the same variables except the species. The use of GLM was justified by the normal distribution of $\mathrm{NC}$ values.
Table 2. The effect of variables on nitrogen content in stomachs of pygmy-field mice and common voles (species relative abundance $=$ rA species; whole rodent community relative abundance $=\mathrm{rA}$ total). Results based on generalised linear model analysis.

\begin{tabular}{lcccc}
\hline & \multicolumn{2}{c}{ Pygmy field mouse } & \multicolumn{2}{c}{ Common vole } \\
& $\chi 2$ & $p$ & $\chi^{2}$ & $p$ \\
\hline Date & & $\mathbf{0 . 0 5 0}$ & 0.169 & $>0.10$ \\
B. length & 0.914 & $>0.10$ & 0.331 & $>0.10$ \\
Year & 2.229 & $>0.10$ & 4.358 & $>0.10$ \\
Sex & 0.156 & $>0.10$ & 2.126 & $>0.10$ \\
Age & 0.133 & $>0.10$ & 2.534 & $>0.10$ \\
rA species & 0.011 & $>0.10$ & 0.658 & $>0.10$ \\
rA total & 0.726 & $>0.10$ & $\mathbf{7 . 6 4 0}$ & $\mathbf{0 . 0 0 6}$ \\
\hline
\end{tabular}

The relatively high number of other mouse species in the set-aside plots, particularly wood mice and the yellownecked mouse, enabled us to undertake a rough comparison of NC values with those of the pygmy field mouse. We analysed it only by one-way ANOVA, where the influence of only the one variable-species-was analysed as a predictor of $\mathrm{NC}$ values.

We also used one-way ANOVA (with only one variablehabitat) to assess variance in NC between habitats (i.e. setaside, rape and wheat fields) for the three dominant rodent species separately (pygmy field mouse, common vole and wood mouse). First, data from Drnholec were used only, then the sample size was increased by including data from Nosislav. The Tukey post-hoc test for detailed analysis was used where the effect of habitat was significant.

All analyses were undertaken using the Statistica 6.0 software package (Statsoft Inc. 2012).

\section{Results}

Based on results of detailed multivariate analysis of pygmy field mouse and common vole populations in set-aside plots (with variables species, body length, sex, age, date, year, total abundance and species specific abundance), a significant difference in the quality of food consumed by both species was found (effect of species: $\chi 2=66.238, p<0.0001$; Table 2, Fig. 2). Pygmy field mouse has a diet with lower and more variable $\mathrm{NC}$ values than common vole.

In the detailed species-specific multivariate analysis, we detected a weak effect of date, however no other variable had a significant effect on pygmy field mouse food quality (Table 2). In late spring and early summer, there was a noticeable decrease in $\mathrm{NC}$ in pygmy field mouse stomachs (Fig. 3). For the common vole, only total abundance showed any effect on food quality, with NC highest in extremely low abundance populations, low at medium abundance and high in more abundant populations (Fig. 3).

The results of the diet quality analysis of mice species shows that there was no significant difference in $\mathrm{NC}$ between pygmy field mice, wood mice and yellow necked mice in setaside habitat (GLM: $\chi^{2}=1.956, p=0.376$, Fig. 2 ). 
Table 3. The differences between NC in crops for pygmy-field mouse (AU), common vole (MA) and wood mouse (AS) (Tukey Post-

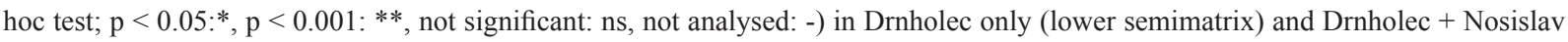
(upper semimatrix).

\begin{tabular}{|c|c|c|c|c|}
\hline \multicolumn{5}{|c|}{ Drnholec + Nosislav } \\
\hline & & Set-aside & Wheat & Rape \\
\hline \multirow{3}{*}{ Only Drnholec } & Set-aside & - & AU ns, $\mathbf{M A}{ }^{* *}$, AS ns & AU ns, MA n, AS ns \\
\hline & Wheat & AU ns, $\mathbf{M A} \mathbf{A}^{* *}, \mathbf{A S} * *$ & - & AU ns, $\mathbf{M A} \mathbf{A}^{*}, \mathbf{A} \mathbf{S}^{* *}$ \\
\hline & Rape & AU ns, MA ns, AS- & AU ns, MA*, AS- & - \\
\hline
\end{tabular}
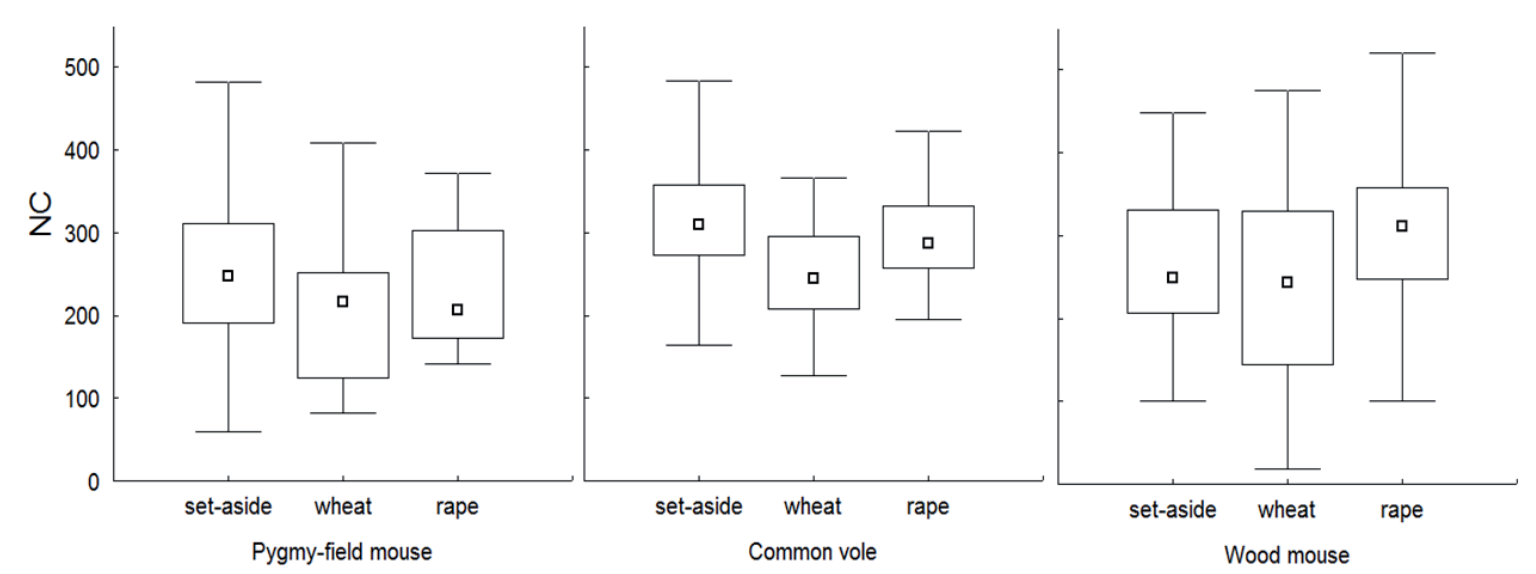

Figure 2. Values for nitrogen content ( $\mathrm{NC}$; in $\mathrm{g} / \mathrm{kg}$ of dry biomass) in the stomach of the three dominant rodent species in the three study habitats (box plots: $25-75 \%$ range, central points: median).
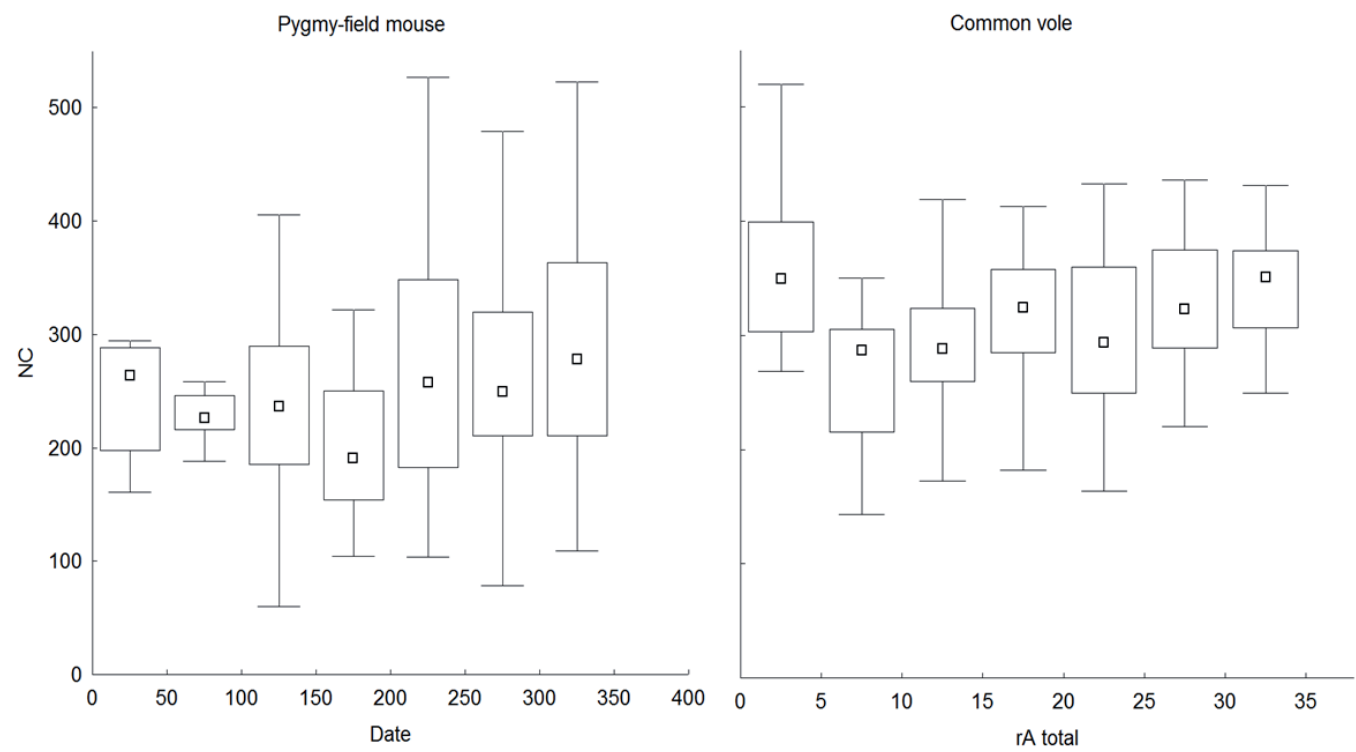

Figure 3. Variables having a significant effect on nitrogen content ( $\mathrm{NC}$; in $\mathrm{g} / \mathrm{kg}$ of dry biomass) in pygmy field mouse (date) and the common vole (total relative abundance). Data based on generalised linear model analysis (box plots: $25-75 \%$ range, central points: median).

According to habitat, there was a significant difference (GLM, $\left.\chi^{2}=33.998, \mathrm{p}<0.0001\right)$ in $\mathrm{NC}$ for common voles living in different habitats (set-aside, rape and wheat) at Drnholec, but not for pygmy field mice (GLM, $\chi^{2}=4.478, \mathrm{p}=0.106$, Fig. 2). While sufficient number of wood mice individuals were only available from the wheat field and set-aside plots, $\mathrm{NC}$ also differed between these habitats as it was higher in setaside $\left(\mathrm{GLM}, \chi^{2}=11.938, \mathrm{p}<0.05\right)$. After increasing the sam- ple size by including samples from Nosislav, the difference in food quality between crops (habitats) was significant for both the common vole (GLM, $\left.\chi^{2}=38.755, \mathrm{p}<0.0001\right)$ and wood mouse (GLM, $\left.\chi^{2}=13.750, \mathrm{p}<0.05\right)$, but not for pygmy field mice (GLM, $\chi^{2}=3.310, p=0.191$, Fig. 2). Tukey post-hoc tests revealed that the ascertained differences were caused by the lower NC of individuals collected from wheat fields than those from rape and set-aside fields in all cases (Table 3 ). 


\section{Discussion}

In this study, we examined the food quality of pygmy field mice with regards to environmental and population factors and compared these data with the food quality of other rodent species. Overall, pygmy field mouse diet did not vary from that of other mouse species, though they had a lower quality diet than herbivorous voles in set-aside plots. Generally, rodent food quality is not much dependent on individuals and external factors. Pygmy field mouse diet quality was affected only by season unlike the food quality of sympatric common vole, which is not so seasonal, but is more affected by population density.

Mice in general display high variability in the levels of stomach NC due to their wide food spectrum (Cepelka et al. 2014, Janova et al. 2016). The poorer quality diet in this study concurs with the results of diet analyses of stomach content undertaken in the same set-aside plot (Heroldova and Janova 2018). In general, pygmy field mice prefer starchy, carbohydrate rich and oily seeds. In the set-aside plots, they consumed weedy herbal species, such as lambs quarters, tumbleweed, chickweed and shepherd's-purse, tended to dominate in the set-aside plots. These seeds contain approximately 20\% NC, while grassy weeds contain only $11 \%$ NC (Zeman 1995). Occasionally, mice ate wheat grains or sunflower seeds taken from the neighbouring fields, which contain about $14 \%$ and $17 \%$ NC, respectively (Zeman 1995). Our own observations suggest that mice partly peel the grains and eats inner parts of seeds, which have more starch and oil, bus less protein, which even decrease consumed nitrogen values.

The diet of common vole, on the other hand, was dominated by the green parts of nutritious alfalfa (mean $\mathrm{NC}=$ $21 \%$ ) at the beginning of set-aside succession, and later by a variety of weeds (e.g., dandelion) with high nutritional values $(\mathrm{NC}=23 \%)$. Grass $(\mathrm{NC}=11 \%)$ and roots $(\mathrm{NC}=22 \%)$ were consumed in winter (Heroldova and Janova 2018). Our own observations show selective consumption of plant species and of the most nutritious parts of the plants available (Heroldova and Janova 2018). In some cases, we observed immature seeds being consumed by common vole alongside the green parts of the plant; which are especially rich in nitrogen (Moir 2010). Similarly, the leaves of leguminous plants have higher protein levels than most cereal grains (Moir 2010), which may well explain the more nutritious diet of common voles compared to pygmy field mice.

In agreement with the results of previous studies, we found no relationship between body length, sex and age on the quality of food consumed by pygmy field mouse or common vole (Palo and Olsson 2009, Janova et al. 2015), despite some studies observing improved food quality in breeding or sub-adult animals (Migula 1969, Obrtel and Holisova 1982, Cepelka et al. 2014).

Date was a significant factor affecting the quality of food consumed by pygmy field mice, but not for voles, as also noted by Janova et al. (2016), who recorded a stronger influence of season on mouse food quality compared with voles. The likely cause of this is the greater variability in mouse diet, which takes advantage of seasonal supply changes through the year, while the green biomass consumed by voles tends to vary little (Zeman 1995). As such, the low availability of ripe seeds in late spring and early summer results in lowered NC values in the diet of mice.

In this study, low-density vole populations (up to 4.5 individuals per 100 traps) exhibited extremely high $\mathrm{NC}$ values, probably as individuals had a wider food choice and little or no competition for food. As population density grew, $\mathrm{NC}$ also increased, in line with observations that in higher population densities is increased reproduction and better quality food is consumed (Butet 1996, Wereszynskaet al. 2007, Palo and Olson 2009, Forbes et al. 2014, Janova et al. 2016).

In general, rodent food quality differs with habitat (Janova et al. 2016), as reflected by the quality of vegetation cover. Wheat fields (seeds and wheat green biomass) provide a much lower NC content than rape and set-aside plots (Zeman 1995), though this was only reflected in the diet of common voles and wood mice and not pygmy field mice. This was almost certainly due to the relatively low pygmy field mouse sample size from the wheat fields, which prevented meaningful statistical analysis despite a clearly lower NC level from the wheat fields (Fig. 2). On the other hand, we were able to confirm that the food quality of pygmy field mice is similar to that of other mouse species living in the same habitat.

Overall, our results indicate that the food quality of pygmy field mice is comparable with that of other mouse species but differs from that of herbivorous voles. For both herbivorous common voles and granivorous mouse species, however, food quality is clearly dependent on habitat and season, with quality varying over time as food availability changes.

Acknowledgements: This research was supported by the Ministry of Education, Youth and Sports of the Czech Republic under project CEITEC 2020 [Grant No. LQ1601]. We would like to thank Dr. K. Roche for improving the English language and for comments to an earlier version of the manuscript.

All work in this study complied with EC Council Directive $86 / 609 / \mathrm{EEC}$ on the experimental use of animals. In addition, the ethical committee of the Czech Academy of Sciences approved all field experiments.

\section{References}

AOAC. 1990. AOAC Official Methods of Analysis. 15th edition, Association of Official Analytical Chemists, Arlington.

Broughton, R.K., R.F. Shore, M.S. Heard, S.R. Amy, W.R. Meek, J.W. Redhead, A. Turk and R.F. Pywell. 2014. Agri-environment scheme enhances small mammal diversity and abundance at the farm-scale. Agr. Ecosyst. Environ. 192:122-129.

Butet, A. 1996. Does food quality drive cycle in Microtus arvalis? Study on a French Atlantic marsh population. Proceedings of the I. European Congress of Mammalogy, Museu Bocage Lisboa, pp. $177-188$

Cepelka, L., M. Heroldova, E. Janova and J. Suchomel. 2014. The dynamics of nitrogenous substances in rodent diet in a forest environment. Mammalia 78:327-333. 
Cepelka, L., M. Heroldova, E. Janova, J. Suchomel and D. Cizmar. 2017. Rodent stomach sample preparation for nitrogen NIRS analysis. Mamm. Biol. 87:13-16.

Cichocki, J., A. Ruprecht and A. Ważna. 2011. Distribution of pygmy field mouse Apodemus uralensis (Pallas, 1811) population in Poland: review of the studies and new data. Fragmenta Faunistica 54:77-85.

Forbes, K.M., P. Stuart, T. Mappes, K.S. Hoset, H. Henttonen and O. Huitu. 2014. Diet quality limits summer growth of field vole populations. Plos One 9:e91113.

Hansson, L. 1979. Food as a limiting factor for small rodent numbers. Oecologia 37:297-314.

Heroldova, M. 1994. Diet of four rodent species from Robinia pseudoacacia stands in South Moravia. Acta Theriol. 39:333-337.

Heroldova, M., J. Zejda, M. Zapletal, D. Obdrzalkova, E. Janova, J. Bryja and E. Tkadlec. 2004. Importance of winter rape for small rodents. Plant Soil Environ. 50:175-181.

Heroldova, M., E. Janova, J. Bryja and E. Tkadlec. 2005. Set-aside plots - source of small mammal pests? Folia Zool. 54:337-350.

Heroldova, M. and E. Janova. 2018. Feeding strategy of two rodent species in a set-aside field and its influence on alimentary tract morphometry. Mammalia, in press. DOI: https://doi.org/10.1515/ mammalia-2017-0106

Holisova, V. and R. Obrtel. 1984. Variation in the trophic niche of Apodemus microps in two different habitats. Folia Zool. 33:4955.

Holisova, V., J. Pelikan and J. Zejda. 1962. Ecology and population dynamics in Apodemus microps Krat. \& Ros. (Mamm.: Muridae). Práce Brněnské základny Čs. Akad. Věd 34:493-540.

Hoofer, S.R., S. Gaschak, Y. Dunina-Barkovskaya, J. Makluk, H.N. Meeks, J.K. Wickliffe and R.J. Baker. 2007. New information for systematics, taxonomy, and phylogeography of the rodent genus Apodemus (Sylvaemus) in Ukraine. J. Mammal. 88:330-342.

Janova, E., J. Bryja, D. Cizmar, L. Cepelka and M. Heroldova. 2015. A new method for assessing food quality in common vole (Microtus arvalis) populations. Eur. J. Wildl. Res. 61:57-62.

Janova, E., M. Heroldova and L. Cepelka. 2016. Rodent food quality and its relation to crops and other environmental and population parameters in and agricultural landscape. Sci. Total Environ. 562:164-169.

Loman, J. 1991. The small mammal fauna in an agricultural landscape in southern Sweden, with special reference to the wood mouse Apodemus sylvaticus. Mammalia 55:91-96.
MacDonald, D.W., F.H. Tattersall, K.M. Service, L.G Firbank, and R.E. Feber. 2007. Mammals, agri-environment schemes and setaside - what are the putative benefits? Mammal Rev. 37:259-277.

Migula, P. 1969. Bioenergetics of pregnancy and lactation in European common vole. Acta Theriol. 14:167-179.

Moir, R.J. 2010. The "carnivorous" herbivores. In: D.J Chivers and P. Langer (eds.), The Digestive System in Mammals: Food Form and Function. Cambridge University Press. pp. 87-102.

Obrtel, R. and V. Holisova. 1982. The trophic niche of Apodemus microps in Southern Moravia. Folia Zool. 31:305-319.

Panteleyev, P.A. 1998. The Rodents of the Palaearctic. Composition and Areas. Pensoft, Moscow.

Palo, R.T. and G.E. Olsson. 2009. Nitrogen and carbon concentrations in the stomach content of bank voles (Myodes glareolus). Does food quality determine abundance? Open Ecol. J. 2:86-90.

Sibly, R.M. and J. Hone. 2002. Population growth rate and its determinants: an overview. Philos Trans. R. Soc. B-Biol. Sci. 357:1153-1170.

StatSoft, Inc. (2012). Electronic Statistics Textbook. StatSoft, Tulsa, OK. WEB: http://www.statsoft.com/textbook/.

Storch, G. 1999. Apodemus uralensis (Pallas.1811). In: A.J. Mitchell-Jones, G. Amori, W. Bogdanowicz, B. Krystufek, P.J.H. Reijnders, F. Spitzenberger, M. Stubbe, J.B.M. Thissen, V. Vohralik and J. Zima (eds.), The Atlas of European Mammals. Academic Press, London. pp. 276-277.

Tattersall, F.H., B.J. Hart, W.J. Manley, D.W. Macdonald and R.E. Feber. 1999. Small mammals on set-aside blocks and margins. Field margins and buffer zones: ecology, management and policy. Appl. Biol. 54:131-138.

Todd, I.A., T.E. Tew and D.W. Macdonald. 2000. Arable habitat use by wood mice (Apodemus sylvaticus). 1. Macrohabitat. J. Zool. 250:299-303

Wereszczynska, A.M., W.K. Nowakowski, J.K. Nowakowski and B. Jedrzejewska. 2007. Is food quality responsible for the coldseason decline in bank vole density? Laboratory experiment with herb and acorn diets. Folia Zool. 56:23-32.

White, T.C.R. 1993. The Inadequate Environment: Nitrogen and the Abundance of Animals. Springer, Berlin.

Zejda, J. and J. Nesvadbova. 1996. Effect of land use change on reproduction in five rodent species. Folia Zool. 45:115-126.

Zeman, L. 1995. The feeding catalogue. VÚVZ (Research Institute of Animal Nutrition) Pohořelice. [In Czech].

Received November 23, 2017 Revised April 16, July 16, 2018 Accepted July 23, 2018 